\title{
Study of the effect of organic acids on the crystal stability of wines
}

\author{
Sofia Cherviak*, Nadezhda Anikina, Nonna Gnilomedova, and Antonina Vesyutova
}

All-Russian National Research Institute of Viticulture and Winemaking Magarach of the RAS, 31 Kirova Str., Yalta 298600, Republic of Crimea, Russian Federation

\begin{abstract}
The loss of solubility of tartaric acid salts of potassium and calcium is the reason for precipitation of crystal sediment in wine. The aim of this work was to study the morphological characteristics of crystal sediment of wines obtained by varying the acidic complex of the must using different technological methods. The approach of must de-oxidation, as well as the introduction of citric acid, provided a decrease in the temperature of saturation with calcium tartrate by $5.8-11.3^{\circ} \mathrm{C}$. At the same time, when introducing the tartaric acid, an inverse relation was noted - the indicator value increased by $34 \%$. According to the results of the study, the relationship between quantitative content of potassium and calcium ions and temperature of saturation with potassium bitartrate $\left(\mathrm{T}_{\text {sat }}(\mathrm{KHTar})\right.$ and calcium tartrate $\mathrm{T}_{\text {sat }}(\mathrm{CaTar})$ ) was not established $(\mathrm{r}=-0.48$ and 0.50 , respectively). It was shown that acidifying of the must with $1 \mathrm{~g} / \mathrm{l}$ of tartaric acid provided the formation of very large crystals of calcium tartrate, and 2 $\mathrm{g} / \mathrm{l}$ of tartaric acid - a stabilizing effect for young wine by the end of the experiment. Regardless the method of varying acid composition of the must, the value of $\mathrm{T}_{\text {sat }}(\mathrm{KHTar})$ was in the range of $14.8-19.5^{\circ} \mathrm{C}$. The obtained results are intended to prove the necessity of preventive measures in wine production to ensure their crystal stability.
\end{abstract}

\section{Introduction}

The loss of solubility of tartaric acid salts of potassium and calcium is the reason of precipitation of crystal sediment in wine [1-3]. Fresh grape must is oversaturated with potassium bitartrate and calcium tartrate. As the content of alcohol increases during alcohol fermentation, the solubility of these salts decreases, causing the precipitation of crystal sediment. The process continues during the clarification and storage of wine, resulting in a partial self-stabilization of the beverage [2].

Destabilization of wines caused by precipitation of calcium tartrate is less common, but more laborious in preventing and regulating the process. Calcium crystal haze can occur as a result of excessive use of calcium carbonate during de-oxidation, as well as filter sheets or stabilizing agents [1].

It is known that the decrease in the content of calcium directly depends on $\mathrm{pH}$ and is based on the interaction of cation with tartrate form of tartaric acid. The content of this

\footnotetext{
* Corresponding author: Sofi4@list.ru
} 
form increases with the growth of $\mathrm{pH}[3,4]$, contributing to more active formation of calcium tartrate and precipitation of generated crystals. The introduction of calcium tartrate seed crystals after de-acidification of wine with calcium carbonate enhances the precipitation of salts.

The $\mathrm{pH}$ of wines in the process of production can be changed in different ways. Thus, a decrease in $\mathrm{pH}$ is provided by acidification of wines with different organic acid preparations, an increase - with the method of de-oxidation by adding the potassium bicarbonate [5, 6]. When studying the effect of different organic acids on spontaneous precipitation of calcium tartrate, it is shown that when added to wine in the amount of $2 \mathrm{~g} / \mathrm{l}$, their inhibitory potential changes in the following sequence: citric $>$ malic $>$ lactic $>$ amber acid [7]. At the same time, according to M. Marques, increasing the content of malic acid is more effective than citric acid to prevent precipitation of calcium tartrate [8]. Currently the problem of calcium tartrate precipitation in wines is still urgent and requires additional research.

The aim of this work was to study the morphological characteristics of crystal sediment of wines obtained by varying the acidic complex of the must using different technological methods.

\section{Materials and methods}

The object of research consisted of sediments formed as a result of crystal destabilization of white table dry wines produced from 'Kokur Belyi' grape variety.

The scheme of preparation of experimental wines included the following stages: destemming and crushing grape, separation of the must (no more than $60 \mathrm{dal} / \mathrm{t}$ grapes), sulfitation (75 mg/ SO $\mathrm{SO}_{2}$ ), settling, fermentation (yeast race '47-K' from the collection of microorganisms of winemaking Magarach (CMW Magarach)), after-fermentation and clarification. The content of organic acids in the must was varied by adding different doses of citric and tartaric acid, as well as by deoxidizing the must with potassium bicarbonate in the amount of $0.45 \mathrm{~g} / \mathrm{l}$ assuming a decrease in mass concentration of tartaric acid by $0.5 \mathrm{~g} / \mathrm{l}$ (Table 1) [6, 9]. Time of exposure was 24 hours. As one of the experimental technological methods, must clarification was provided at a temperature of $0{ }^{\circ} \mathrm{C}$ for 24 hours.

Table 1. Scheme of the experiment

\begin{tabular}{|c|l|}
\hline $\begin{array}{c}\text { Variant } \\
\text { No. }\end{array}$ & \multicolumn{1}{|c|}{ Variant of the experiment } \\
\hline 1 & Control \\
\hline 2 & $\begin{array}{l}\text { Clarification of the must at a temperature } 0^{\circ} \mathrm{C} \\
\text { during } 24 \text { hours }\end{array}$ \\
\hline 3 & $+0,5 \mathrm{~g}$ citric acid \\
\hline 4 & $+1 \mathrm{~g}$ citric acid \\
\hline 5 & $+1 \mathrm{~g}$ tartaric acid \\
\hline 6 & $+2 \mathrm{~g}$ tartaric acid \\
\hline 7 & $+0.45 \mathrm{~g} / \mathrm{KHCO}_{3}$ \\
\hline 8 & $+0.45 \mathrm{~g} / \mathrm{KHCO}_{3}+0.5 \mathrm{~g}$ citric acid \\
\hline 9 & $+0.45 \mathrm{~g} / \mathrm{KHCO}_{3}+1 \mathrm{~g}$ tartaric acis \\
\hline
\end{tabular}

Produced wines were analyzed in accordance with physicochemical indicators: volume fraction of ethyl alcohol, mass concentration of titratable acids, total dry extract, potassium and calcium ions and $\mathrm{pH}$ value. The research was carried out using methods adopted in techno-chemical control of winemaking industry [10]. The profile of organic acids (tartaric, 
malic, lactic, citric, amber) as well as the content of sugars and glycerin, was determined using method of high performance liquid chromatography (Shimadzu LC20 Prominance, Japan). Calculation of forms of tartaric acid was carried out in accordance with [11]. Determining of the saturation temperature with potassium bitartrate and calcium tartrate $\left(\mathrm{T}_{\text {sat }}(\mathrm{KHTar})\right.$ and $\mathrm{T}_{\text {sat }}(\mathrm{CaTar})$ ) was provided in accordance with [12].

Wines samples, each of $0.75 \mathrm{l}$ by volume, were aged for 3 months at a temperature of $12-14{ }^{\circ} \mathrm{C}$, corresponding to the conditions of wine storage.

The bottle sediment was assessed using visual examination in the transmitted ray of light of the slit-lamp. Identification and measuring of crystals were carried out using method of light microscopy on Micmed-5 microscope (LOMO JSC, Russia) with a system of visualization and Image Scope M software. The sediment was sampled in triplicate from every testing variant. At least ten fields of vision of the micropreparation were analyzed. Description of morphological features of crystals with their identification was carried out in accordance with the methodological approaches earlier proposed by us [12].

\section{Results and discussion}

The analysis of wines under study showed (Table 2) that all samples in terms of value of physicochemical indicators corresponded to the requirements of regulatory documents; the residual sugar content in the samples did not exceed $4 \mathrm{~g} / \mathrm{l}$ and corresponded to the level of dry wines. Volume fraction of ethyl alcohol, regardless the variant of test, slightly varied and was in the range of $12.0-13.1 \%$. Low content of lactic acid in the samples (0.02-0.05 $\mathrm{g} / \mathrm{l}$ ) indicated the absence of malic-lactic fermentation.

The organic acid profile showed quantitative transformation of citric acid, introduced at the stage of the must, into the wine. At the same time, it is pointed out that added tartaric acid partially precipitates during the process of fermentation, as evidenced by its lower actual content in the wine compared to the expected one - the difference is 0.1-0.3 g/l.

Table 2. Physicochemical indicators of base wine

\begin{tabular}{|c|c|c|c|c|c|c|c|c|}
\hline \multirow{3}{*}{$\begin{array}{c}\text { Variant } \\
\text { No. }\end{array}$} & \multirow{3}{*}{$\begin{array}{c}\text { Volume } \\
\text { fraction of } \\
\text { ethyl } \\
\text { alcohol, \% }\end{array}$} & \multirow{3}{*}{$\mathrm{pH}$} & \multicolumn{6}{|c|}{ Mass concentration, g/l } \\
\hline & & & \multirow{2}{*}{$\begin{array}{c}\text { titratabl } \\
\text { e acids }\end{array}$} & \multirow{2}{*}{$\begin{array}{c}\text { total } \\
\text { dry extract }\end{array}$} & \multicolumn{4}{|c|}{ organic acids } \\
\hline & & & & & citric & tartaric & malic & lactic \\
\hline 1 & 13.0 & 3.4 & 5.3 & 18.1 & 0.3 & 2.6 & 1.4 & 0.05 \\
\hline 2 & 12.7 & 3.4 & 5.8 & 17.7 & 0.3 & 2.9 & 1.4 & 0.02 \\
\hline 3 & 12.5 & 3.3 & 6.3 & 18.9 & 0.8 & 2.9 & 1.4 & 0.04 \\
\hline 4 & 12.5 & 3.2 & 7.0 & 19.5 & 1.3 & 2.8 & 1.3 & 0.03 \\
\hline 5 & 11.8 & 3.1 & 6.5 & 17.8 & 0.3 & 3.5 & 1.3 & 0.03 \\
\hline 6 & 12.7 & 3.0 & 8.3 & 20.9 & 0.3 & 4.3 & 1.3 & 0.02 \\
\hline 7 & 12.7 & 3.5 & 4.4 & 18.3 & 0.3 & 2.1 & 1.4 & 0.04 \\
\hline 8 & 12.8 & 3.4 & 5.5 & 17.9 & 0.8 & 2.2 & 1.4 & 0.02 \\
\hline 9 & 13.1 & 3.2 & 6.0 & 18.3 & 0.3 & 2.5 & 1.3 & 0.03 \\
\hline
\end{tabular}

The $\mathrm{pH}$ value of the studied samples was in the range of 3.0-3.5. At the same time, the minimum value of the indicator was ensured by the introduction of tartaric acid into the must in the amount of $2 \mathrm{~g} / \mathrm{l}$, and the maximum value - by de-oxidation of the must, which was confirmed by mass concentration of this acid - 4.3 and $2.1 \mathrm{~g} / \mathrm{l}$, as well as titratable acids - 8.3 and $4.4 \mathrm{~g} / \mathrm{l}$, respectively.

The results of the study of physicochemical wine indicators when varying the acidic complex of the must showed that using of must de-oxidation, as well as introduction of citric acid, provided a significant decrease in the temperature of saturation with calcium 
tartrate (Table 3). It should also be noted, that while adding the citric acid in the amount of $0.5 \mathrm{~g} / \mathrm{l}$, the value of $\mathrm{T}_{\text {sat }}(\mathrm{CaTar})$ decreases to negative values. At the same time, when introducing the tartaric acid, an inverse correlation is observed - the value of the indicator is increased by $34 \%$. Regardless the method of varying acid composition of the must, the value of $\mathrm{T}_{\text {sat }}(\mathrm{KHTar})$ was in the range of $14.8-19.5^{\circ} \mathrm{C}$.

Table 3. Physicochemical indicators of wines

\begin{tabular}{|c|c|c|c|c|c|c|c|c|}
\hline \multirow{2}{*}{$\begin{array}{c}\text { Variant } \\
\text { No. }\end{array}$} & \multicolumn{2}{|c|}{$\mathrm{T}_{\text {sat, }}{ }^{\circ} \mathrm{C}$} & \multicolumn{2}{|c|}{$\begin{array}{c}\text { Presence of } \\
\text { crystals }\end{array}$} & \multicolumn{2}{|c|}{$\begin{array}{c}\text { Mass concentration of } \\
\text { tartaric acid forms, g/l }\end{array}$} & \multicolumn{2}{c|}{$\begin{array}{c}\text { Mass } \\
\text { concentration of } \\
\text { ions, mg/l }\end{array}$} \\
\cline { 2 - 10 } & KHTar & CaTar & KHTar & CaTar & $\begin{array}{c}\text { bitartrate- } \\
\text { ions (HT) }\end{array}$ & $\begin{array}{c}\text { tartrate-ions } \\
\left(\mathrm{T}^{2-}\right)\end{array}$ & $\mathrm{K}^{+}$ & $\mathrm{Ca}^{2+}$ \\
\hline 1 & 17.8 & 7.3 & + & + & 1.5 & 0.14 & 439 & 50.5 \\
\hline 2 & 18.9 & 7.8 & + & + & 1.9 & 0.19 & 527 & 56.1 \\
\hline 3 & 17.7 & -4.0 & + & + & 1.8 & 0.10 & 455 & 52.1 \\
\hline 4 & 19.5 & 0.5 & + & + & 1.6 & 0.11 & 307 & 59.9 \\
\hline 5 & 18.5 & 9.8 & + & + & 1.8 & 0.10 & 592 & 65.8 \\
\hline 6 & 17.5 & 9.8 & + & - & 1.9 & 0.07 & 463 & 61.0 \\
\hline 7 & 17.8 & 1.5 & + & + & 1.4 & 0.21 & 259 & 40.1 \\
\hline 8 & 16.3 & -0.5 & + & + & 1.5 & 0.18 & 358 & 51.3 \\
\hline 9 & 14.8 & 13.0 & + & + & 1.5 & 0.11 & 745 & 57.7 \\
\hline
\end{tabular}

Mass concentration of calcium in wines before storage varied from 40 to $66 \mathrm{mg} / \mathrm{l}$, the smallest amount of the component was determined in the variant with de-oxidation. It indicates its more active transformation from the state of solution into sediment in the form of calcium tartrate in the variant with a higher $\mathrm{pH}$ value. For the same reason, in the variants of the experiment with $\mathrm{pH}$ 3.0-3.2, more calcium has remained by $14.3-30.3 \%$, in comparison with the control. Mathematical analysis of the obtained data (Fig. 1, 2) indicates that there is no relationship between the quantitative content of potassium and calcium ions and the temperature of saturation with potassium bitartrate and calcium tartrate ( $r=-0.48$ and 0.50 , respectively).

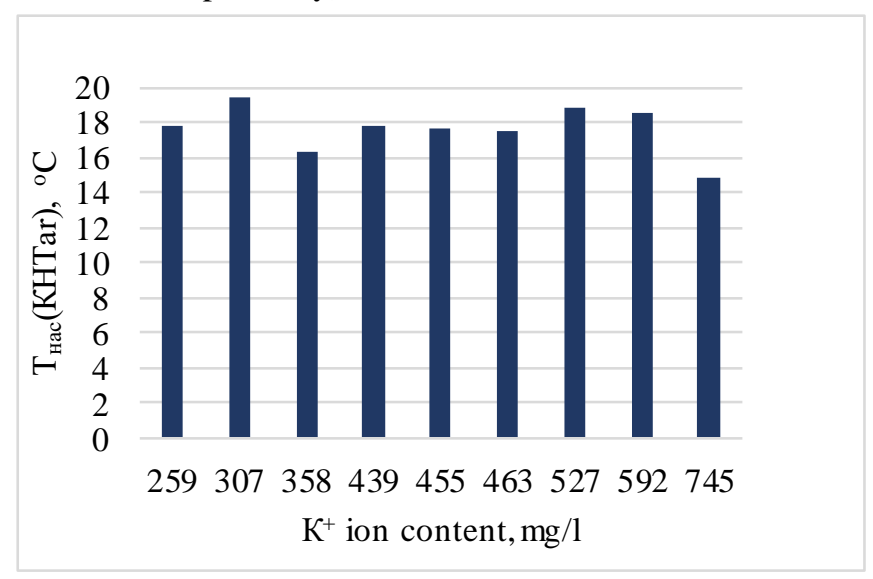

Fig. 1. Dependence of $\mathrm{T}_{\text {sat }}(\mathrm{KHTar})$ from $\mathrm{K}^{+}$content

Calculation of forms of tartaric acid depending on the $\mathrm{pH}$ of wine indicates that the content of bitartrate form of tartaric acid in the studied samples consisted of 1.4-1.9 g/l. The sample with de-oxidation was characterized by the minimum indicator value. Variants of the experiment with introduction of $2 \mathrm{~g} / \mathrm{l}$ of tartaric acid and clarification at $0^{\circ} \mathrm{C}$ differed in 
the maximum value. At the same time, the fraction of tartrate forms of tartaric acid in the above described samples varied by 2.7 .

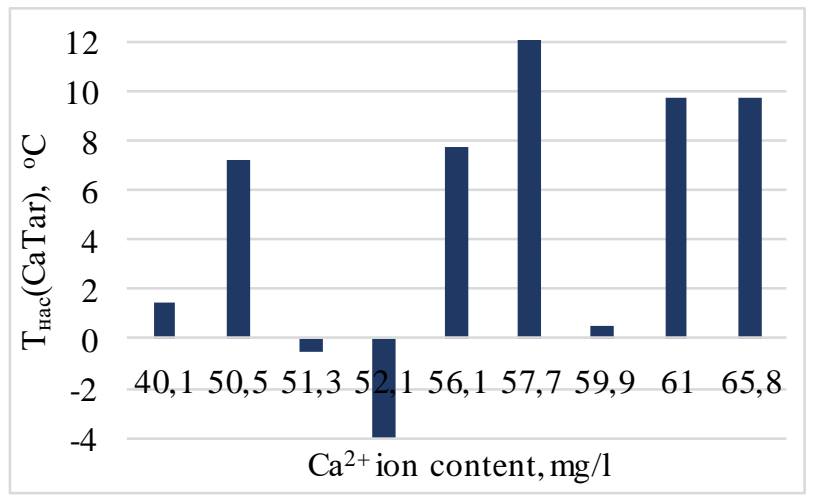

Fig. 2. Dependence of $\mathrm{T}_{\text {sat }}(\mathrm{CaTar})$ from $\mathrm{Ca}^{2+}$ content

Variation of qualitative and quantitative content of organic acids made it possible to assess their effect on spontaneous crystal formation (Table 4).

Table 4. Characteristics of crystal sediment

\begin{tabular}{|c|l|l|l|}
\hline \multirow{2}{*}{$\begin{array}{l}\text { N } \\
\text { o. }\end{array}$} & \multirow{2}{*}{ Visual sediment characteristics } & \multicolumn{2}{|c|}{$\begin{array}{c}\text { Characteristics of crystals in sediment } \\
\text { (microscopic examination) }\end{array}$} \\
\cline { 3 - 4 } & & \multicolumn{1}{|c|}{$\begin{array}{c}\text { KHTar* } \\
\text { CaTar** }\end{array}$} \\
\hline & wine crust, painted in the color of & $\begin{array}{l}\text { irregular-shaped interlocked } \\
\text { crystals }\end{array}$ & large crystals \\
\hline 2 & $\begin{array}{l}\text { separate cluster crystals, sediment } \\
\text { volume is significantly lower, than } \\
\text { in No. } 1\end{array}$ & $\begin{array}{l}\text { large irregular-shaped } \\
\text { interlocked crystals }\end{array}$ & $\begin{array}{l}\text { abundance of large } \\
\text { crystals (larger than in } \\
\text { No. 1) }\end{array}$ \\
\hline 3 & dense crust* & $\begin{array}{l}\text { large irregular-shaped } \\
\text { interlocked crystals }\end{array}$ & large crystals* \\
\hline 4 & dense crust* & $\begin{array}{l}\text { abundance of small and } \\
\text { large crystals }\end{array}$ & $\begin{array}{l}\text { abundance of small } \\
\text { crystals }\end{array}$ \\
\hline 5 & $\begin{array}{l}\text { separate cluster crystals, without } \\
\text { crust, very little sediment }\end{array}$ & $\begin{array}{l}\text { separate large interlocked } \\
\text { crystals }\end{array}$ & $\begin{array}{l}\text { abundance of very large } \\
\text { and medium-size } \\
\text { crystals }\end{array}$ \\
\hline 6 & $\begin{array}{l}\text { separate cluster crystals, without } \\
\text { crust, very little sediment }\end{array}$ & $\begin{array}{l}\text { separate very large } \\
\text { interlocked crystals }\end{array}$ & NA \\
\hline 7 & dense bright crust & large crystals & large crystals \\
\hline 8 & dense bright crust & $\begin{array}{l}\text { regular-shaped elongated } \\
\text { crystals }\end{array}$ & large crystals \\
\hline 9 & dense crust* & $\begin{array}{l}\text { irregular-shaped interlocked } \\
\text { crystals }\end{array}$ & large crystals \\
\hline
\end{tabular}

* small crystals - length 11-50 $\mu \mathrm{m}$, large - 151-350 $\mu \mathrm{m}$, very large - more than $350 \mu \mathrm{m}$ [12]

** small crystals - length 5-25 $\mu \mathrm{m}$, medium-size - 26-100 $\mu \mathrm{m}$, large - 101-150 $\mu \mathrm{m}$, very large - more than $150 \mu \mathrm{m}$.

Characteristics of crystal sediment by visual assessment and microscopic examination showed that potassium bitartrate was registered in the sediments of all studied samples. Volume of the formed sediment and morphological features of crystals in the experimental wines differed significantly. Thus, the samples with introduction of tartaric acid in the 
amount of 1 and $2 \mathrm{~g} / \mathrm{l}$ were characterized by the minimum amount of sediment, without formation of specific "crust" in the bottom of a bottle. Distinctive feature of the first sample was the presence of very large crystals of calcium tartrate, and of the second one - the abundance of large crystals of potassium bitartrate and the absence - of calcium tartrate, which is probably due to lower $\mathrm{pH}$, compared to other wines.

Despite a significant increase in the total concentration of tartrate ions, the shift in $\mathrm{pH}$ to a more acidic side have led to redistribution of forms of tartaric acid with a decrease in the proportion of the effector - the reacting with calcium tartrate-anion. Thus, the acidification of the must with $2 \mathrm{~g} / \mathrm{l}$ of tartaric acid has provided a stabilizing effect on the young wine, at least during the experiment (3 months of storage).

Variant No. 4 (acidification with citric acid) was distinguished by the presence of both large and small crystals of calcium tartrate in the composition of the sediment, indicating the continuing process of their formation and growth. Crystals of calcium tartrate in the Variant No. 5 differed in a large size, explained by an increase in the content of tartaric acid.

The effect of de-oxidation of the must with subsequent recovering of acidity with tartaric and citric acids on the qualitative composition and morphological features of the crystal sediment of wines was not established.

\section{Conclusion}

The studies conducted allow us to make a conclusion that patterns of qualitative and quantitative content of organic acids significantly influence the crystal stability of wines, as evidenced by morphological features of potassium bitartrate and calcium tartrate crystals. The results obtained are intended to prove preventive measures during the production of wines to ensure their crystal stability.

\section{References}

1. R.S. Jackson, Wine Science: Principles and Applications (Academic Press., 4th ed., 2014)

2. P.P. Lankhorst, B. Voogt, R. Tuinier, B. Lefol, P. Pellerin, C. Virone, J. Agric. Food Chem., 65(40), 8923-8929 (2017)

3. A. Bajul, V. Gerbaud, S. Teychene, A. Devatine, G. Bajul, Journal of Crystal Growth 472, 54-63 (2017)

4. V.G. Gerzhikova, N.S. Anikina, A.V. Vesyutova, M.V. Ermikhina, O.V. Ryabinina, Magarach. Viticulture and winemaking, 22(111), 69-72 (2020)

5. P. Comuzzo, F. Battistutta Acidification and $p H$ Control in Red Wines (Red Wine Technology, Academic Press, 2019)

6. A.L. Waterhouse, G. L. Sacks, D.W. Jeffery, Understanding Wine Chemistry (Wiley, 1st edition, 2016)

7. A.D. Coulter, M.G. Holdstock, G.D. Cowey, C.A. Simos, P.A. Smith, E.N. Wilkes, The Australian Wine Research Institute: 60th Anniversary, 21, 627-641 (2015)

8. M. Marques. Inhibitors of calcium tartrate in wines (Instituto Superior Técnico, Lisbon, Portugal. 2014)

9. The tricks and traps of deacidification Grapegrower \& Winemaker, 642, 56-57 (2017)

10. Compendium of international methods of wine and must analysis. Paris. (2017)

11. V.G. Gerzhikova, N.S. Anikina, A.V. Vesyutova, M.V. Ermikhina, O.V. Ryabinina, E.A. Slastya, D.P. Tolstenko, Magarach. Viticulture and winemaking, 22 (114), 368-372 (2020)

12. N.V. Gnilomedova, S.N. Cherviak, A.V. Vesyutova, Magarach. Viticulture and winemaking, 22(111), 73-76 (2020) 